\title{
CYSTIC FIBROSIS AND THE ROLE OF THE PHYSIOTHERAPIST
}

ANNE MIOT, B.Sc. (Physio), (Witwatersrand), J. M. PETTIFOR, M.B. B.Ch., F.C.P. (S.A.), Ph.D. (Med), I. REEF, M.B. B.ch., F.R.C.P.*

\section{SUMMARY}

Cystic fibrosis is an inherited disease, the major problems being pancreatic malabsorption and progressive respiratory involvement, although numerous other organs may also be involved. The pulmonary pathology and the role of the physiotherapist in the treatment of cystic fibros $s$ is discussed. The physiotherapist plays an important role in the management of the child with cystic fibrosis, not only from the point of view of maintaining maximal pulmonary function but also because she comes into close contact with the family and can help in optimising the acceptance of the child into the family situation.

\section{INTRODUCTION}

Cystic fibrosis was first described as a clinical entity some forty years ago; however, the characteristic electrolyte abnormalities in the sweat, which have become the criteria for diagnosis, were only discovered twenty years later. Cystic fibrosis, a genetic disease inherited as an autosomal recessive, is characterised by a generalised dysfunction of exocrine glands. This leads to three major features; pancreatic insufficiency and intestinal malabsorption, chronic pulmonary disease, and elevated concentrations of sodium and chloride in the sweat. Many other organs, such as the liver and male reproductive system, are involved as well, but their involvement is usually overshadowed by the problems produced by the pancreatic and respiratory disease.

Over the past two decades, significant strides have been made in the treatment of the cystic fibrosis, so that now it is the exception rather than the rule that sufferers do not reach adolescence. Despite these advances in treatment, the basic biochemical defect of this disease, which affects so many organs, is still unknown. Although pancreatic insufficiency with its concommitant malabsorption and failure to thrive, is often the first clinical clue that the patient is suffering from cystic fibrosis, it is usually the progressive pulmonary involvement with eventual respiratory failure that leads to the early mortality in the disease. It is for this reason that the control of the pulmonary compliçations has played such an important role in the improvement in prognosis that has occurred over the past twenty years.

\section{THE PATHOLOGY OF THE RESPIRATORY TRACT IN CYSTIC FIBROSIS}

The major area of involvement in cystic fibrosis is initially the small airways. At birth the lungs are histologically normal. However the patient is prone to infection. Infection leads to hypertrophy of the mucous sub-mucosal glands and an increase in viscosity and production of the respiratory mucus. The infection of cystic

* Cystic Fibrosis Clinic, Department of Paediatrics, Johannesburg Hospital, Private Bag X39, Johannesburg, South Africa.

Received 1 May 1981.

\section{OPSOMMING}

Sistiese fibrose is 'n oorerflike siekte, warvan die hoofprobleme pankreasmalabsorpsie en progressiewe respiratoriese versaking is, hoewel verskeie ander organe ook betrokke kan wees. Die long patologie en die rol van die fisioterapeut in sistiese fibrose word bespreek. Die fisioterapeut speel 'n belangrike rol in die hantering van die kind met sistiese fibrose, nie slegs van die oogpunt om maksimale longfunksie te behou nie, maar ook daar sy in noue kontak met die familie kom en karf help om die aanvaarding van die kind in die familiesituasie te bevorder.

fibrosis is a bronchiolitis, affecting predominantly the small bronchi and bronchioli. This leads to ulceration and scarring of the small airways with bronchiolar stenosis and obliteration. Excess mucus production leads to obstruction with associated airtrapping or collapse of alveoli. The infection gradually spreads to involve the surrounding parenchyma and the larger bronchi. The typical pattern of chronic bronchitis with obstruction of the large and smaller airways, hyperinflation of the lungs and bronchiectasis is then seen. The bronchiectasis classically involves all segments of the lung. Concommitant with these changes is the development of pulmonary hypertension leading to right ventricular hypertrophy and cor pulmonale. A further aspect of the pulmonary pathology which has not been adequately explained is the increased incidence of asthma-like bronchospasm responsive to bronchodilator or steroid therapy.

Thus clinically in the early stages of the disease, the only symptom may be a dry repetitive cough which often passes unnoticed by the mother or general prac-titioner. This may progress to a picture similar to bronchiolitis in the infant, with tachypnoea, hyperinflation and expiratory rhonchi. The cough may become paroxysmal and in the young infant is often associated with vomiting. Recurrent episodes of patchy bronchopneumonia also occur, these often being associated with Staphylococcus aureus infections. Later in the disease the cough is usually productive, but the amount of sputum varies considerably depending on the severity of the bronchiectasis and the presence or absence of acute infection. Clubbing of the fingers is often seen in young children suffering from cystic fibrosis, more particularly in those with more severe lung involvement. As the disease progresses, the child becomes progressively more disabled, with central cyanosis appearing and becoming persistent. Right-sided cardiac failure may occur, and episodes of haemoptysis become more frequent. Pneumothorax has been reported to occur particularly in the older patient. As the patient becomes older, the incidence of colonization of the respiratory tract with Pseudomonas aeruginosa becomes more common. Once established, eradication of the organism is almost impossible despite vigorous treatment with appropriate intravenous antibiotics. The role that this colonisation plays in the progressive deterioration of respiratory function is unclear, as are the 
reasons why colonization should occur in scme patients with cystic fibrosis and not in others.

If treatment is to be of any benefit, it is cbvious that therapy should be aimed at preventing the progressive structural damage that occurs due to recurrent infections and the increased secretion of viscid mucus. Why the patient with cystic fibrosis should be prone to respiratory infection early on in the disease is unclear; however there are two known defects in respiratory function. Firstly, cilial activity of the respiratory mucous membranes is abnormal. It is thought that normal cilial action is an important means of clearing bacteria and debris from the smaller airways. Thus in the patient with cystic fibrosis this means of bronchial toilet is impaired. Secondly, the increased secretion of viscid mucus tends to obstruct airways and provides a good naidus for bacterial proliferation. Thus therapy should be aimed at two main areas:

- the prevention of or vigorous treatment of respiratory infections and

the adequate clearance of the viscid mucus.

\section{THE ROLE OF THE PHYSIOTHERAPIST IN THE TREATMENT OF CYSTIC FIBROSIS}

The physiotherapy treatment of a child with cystic fibrosis is a relatively routine matter and will only be discussed briefly. However, our patient is not simply a child whose lungs produce excessive quantities of thick and tenacious secretions. He is a child disabled, to a greater or a lesser degree, by a disease for which there is, at the moment, no known cure. In addition, cystic fibrosis is a family disease and it will affect every member of the family to some extent. To further complicate the picture, it is a genetically inherited disease. Consequently, while being primarily concerned with clearing the airways of our patient, we should be aware that our role as physiotherapists must go much further. We are handling a disabled child, and a potentially disabled family, and we should aim, in our treatment, to achieve the highest possible quality of life, both for the child, and for his family.

It is our purpose to share some of the thoughts we have on securing as bright a future as possible for this unit of people.

Our role starts when the diagnosis is made. The doctors will already have given the diagnosis to the parents, and discussed the prognosis with them. However, most parents, at some stage, will wish to discuss it further with us. There are two points to remember when replying to the questions that one will be asked. One is that we are now aware that cystic fibrosis can be present in a very mild form, and the other is that the initiation of early treatment, coupled with the advances in therapy, have improved the prognosis enormously (see pathology). We must therefore remember that the disease has a very variable, although inevitably downward course, so that the prognosis must be given cautiously, as the diagnosis is not synonymous with death in childhood.

Our initial responsibility is to instruct the parents in the nature of the disease as it affects the lungs, and to ensure that they understand very clearly that, in the the event of pulmonary involvement, their child's prognosis depends very largely on the effective elimination of secretions and the control of infection. This information must be given sensitively, so that the parents are not left with the feeling that they themselves will be solely responsible for any acute exacerbation of their child's pulmonary problem.

To quote Lindy Burton (1974) — "Little is worse for parents than learning that their child has a lifethreatening illness. The diagnosis itself implies pain and helplessness, and seems to preclude all joyful expectations for a normal satisfying life together. As such, it is responded to, not just as a threat for the future, but as a real and actual loss beginning at the moment the news is broken."

People will respond to this diagnosis differently, depending on a variety of background factors. Denial of either the diagnosis or the prognosis is not uncommon, particularly by the fathers. However, this denial can in fact, cushion the parents against reality, thus making an intolerable situation tolerable for the moment. It has been found that this initial denial is reduced where the parents are intimately involved with the care of their afflicted child. The knowledge that the mother can, and indeed must, do a tremendous amount to help her child achieve the best possible quality of life seems to go a long way in allowing her to accept the diagnosis. It offers a challenge, and can become another device for making the intolerable tolerable, and for diminishing the feelings of guilt and lowered selfesteem that some people show when told that their child has a genetically transmitted disease.

These above facts colour our discussions with the parents. The mother is, for obvious reasons, more involved with the treatment, but we must make every effort to ensure the involvement, not only of the father, but indeed the whole family.

Having explained why the treatment is essential, and having structured the explanation to suit the individual, we stress that the home programme should achieve the maximum in the shortest possible time, should be comfortable and as much fun as the family can make it. Long, distressing and boring treatment sessions over the years will cause an initial resentment and an eventual rebellion in the child. This we must try to avoid.

We teach the positions for postural drainage, the techniques of precussion, vibration and assisted coughing and the use of the nebuliser of choice. For the reasons described above, we do not hand out lists of specific activities. We prefer to encourage the mother to develop her own individual home programme within the broad framework of what is necessary.

We have found that some mothers feel a terrible guilt about transmitting an illness to their children, while others teel a dreadtul despair when they look into the future. These feelings will manifest themselves in various ways. These we must recognise for what they are - individual ways of coping with their problems. One might find aggression, and this one should ignore; or one might find an overzealousness, and this one should try to discourage. We have seen some mothers become so obsessed with the child's treatment, particularly the physiotherapy side of it, that they allow the child very little opportunity for any other activity during the day. Others develop fixations about securing a productive cough, and subject their children to the most extraordinary indignities in order to achieve their objective. One needs to explain that all "cystics" are not harbouring buckets-full of secretions in their lungs all the time, and that while keeping the lungs clear is important, helping the child to lead as normal and as happy a life as possible, is of even greater importance. Haller (1970) has commented - "If the child is permitted to focus on his disease, or his deformity, so that the image dominates him, he will remain chronically ill despite excellent clinical care. If a child can be convinced that his disability is only relative, half of the therapeutic battle is won."

We should give guidelines on the frequency of home treatment. We advise that, if the child is productive, the programme should be carried out twice a day, first thing in the morning and last thing at night 
if possible, not immediately after a meal; that the frequency should be stepped up if the secretions increase, and that one treatment per day is enough if the child's cough is unproductive. In the case of a young child who only shows signs of mild pulmonary involvement, we advise that a short programme of postural drainage and "breathing exercises" should be carried out once a day. This is to accustom the child to the treatment so that it becomes simply a part' of his dally life. Hopefully, this approach will make it easier for the child to accept the treatment when it really becomes necessary.

We stress the importance of physical activity - any activity appropriate to the age of the child. This is both for the purpose of mobilising secretions and producing a cough, and for the sense of well-being that any such activity almost inevitably brings, provided of course that it is done within the limits of the child's capacity. Without having done any controlled studies on this subject, it is difficult to say whether a "well cystic" jogs because he is well, or whether jogging makes a "cystic" well.

Another of our responsibilities is to instruct the mothers in infection control, teaching them how to clean the equipment used so as to minimise the danger of reinfection.

With more and more "cystics" surviving into their teenage years it is becoming of paramount importance to investigate, and teach ways of helping the teenager to clear his own lungs, thus securing as far as possible the independence so necessary for the transition from adolescence to adulthood. These methods include self-nebulisation, self-postural drainage using the forced expiration technique, possibly mechanical percussions, and self-assisted coughing, such as coughing against a closed glottis. It has been suggested that vigorous and self-directed coughing may be all that is required for effective bronchial toilet.

Contact with the child on admission to hospital for treatment of an acute infection is often a time when the role of physiotherapy can be reinforced. Here again, the actual physiotherapy treatment is simple, but it is complicated by the fact that the child has, in a sense, become a product of his disease in terms of his behavioural responses to it. No child can actually enjoy being hooked up to an intravenous drip, being tipped, percussed and made to cough vigorously, and the "cystic" children are no exception. As with any child who has a chronic debilitating and socially unacceptable illness, resentment and lack of co-operation may often be present. I hese behaviour patterns should be recognized for what they are, and we should try, if necessary with the help of the psychiatrist attached to the team, to secure the co-operation of the child. All of this means that we are not dealing with a chifd who simpiy requires "chest physiotherapy". We have found that one must set achievable goals, depending on the child's condition at that moment, and then very firmly and gently, insist on his co-operation. It is also very necessary to allow the mother to participate in the care of her child, while still ensuring that she has the rest that she needs as we take over the responsibility for clearing his chest.

Finally, in the terminal stages of the disease, the physiotherapist's role should become more supportive. Physiotherapy should not be withheld but should be tempered with the understanding that one's role now is to try and achieve maximum comfort for the dying child.

In this paper it is obviously impossible to go into the methods of physiotherapy employed in each of the age groups of children suffering cystic fibrosis. However, it is apparent that physiotherapy and the physiotherapist play central roles in the handling of children with cystic fibrosis. It is our hope that this article has helped in defining the extended roles of the physiotherapist and in outlining the pathophysiology of the lung disease associated with cystic fibrosis.

\section{References}

Burton L. (1974). Tolerating the intolerable - the problems facing parents and children following diagnosis in: Care of the child facing death. Routledge and Kegan Paul. London. Pp 16-34.

Haller, J. A. (1970). A healthy attitude towards chronic illness - quoted by Burton L. (1974). Tolerating the intolerable - the problems facing parents and children following diagnosis in: Care of the child facing death. Routledge and Kegan Paul. London. Pp 16 - 34.

Reid L. (1980). Cardiopulmonary Pathology, in: Perspectives in Cystic Fibrosis - Proceedings of the 8th International Cystic Fibrosis Congress. Ed. J. M. Sturgess. Canadian Cystic Fibrosis Foundation. Toronto. Pp. $198-214$. 